\title{
The Attachments of Porphyra umbilicalis, (L.) J. Ag.
}

\author{
BY
}

VIOLET M. GRUBB, B.Sc.

With Plate I and eight Figures in the Text.

\section{INTRODUCTION.}

R ASAL holdfasts are organs which are characteristic of the vast majority of marine algae, and are found exhibiting every degree of complexity from simple rhizoids to massive hapterons.

The attachment in the Rhodophyceae consists generally of a disc or root-like structure composed originally of filaments formed by the outgrowth of the lower cells of the thallus (5). These filaments may lose their individual structure and become welded into a solid parenchymatous mass (5), but whether this takes place or not the adherence of the basal organ to the substratum is surprisingly strong and adequate to withstand the constant strain to which marine algae are subjected, for a longer or shorter period each day, by the movement of the waves. Certain genera are invariably found as epiphytes or parasites, but the details of their attachments have only been worked out in a few cases. In the well-known case of specialized parasitism-that of Polysiphonia fastigiata on Ascophyllum nodosum - the attaching filaments are recorded as penetrating among the cells of the host but not actually entering them (8).

\section{Habit and Growth of the Species of Porphyra.}

During certain seasons of the year Porphyra is one of the most common of the red algae that inhabit the coasts of the Northern Hemisphere, and considering its frequency it is curious that its interesting method of attachment has never been investigated in detail. The material for this account was obtained mainly from Durlston Bay, near Swanage, where the three varieties of Porphyra umbilicalis, (L.) J. Ag., occur-var. linearis, Grev., var. vulgaris, Ag., and var. laciniata, Ag.

During the summer months there is no sign of the purple fronds, but about November the rocks become covered with sheets of the narrow ribbons; this narrow form was originally separated as a different species

[Annals of Botany, Vol. XXXVII. No. CXLV. January, 1923.] 
under the name of $P$. linearis, Grev., but Harvey (6) proposed that it should be included as a var. linearis of $P$. vulgaris, as he considered it to be only a growth-form of that type; this conclusion is fully upheld by the succession of forms under observation at Swanage.

The majority of the very narrow fronds are fertile and remain so throughout the season. On the rocks near high-water level the fronds hardly increase at all in size during the winter and spring, but remain approximately 5 to $\mathrm{I} 5 \mathrm{~cm}$. in length and 0.3 to $\mathrm{I} \mathrm{cm}$. in breadth. Porphyra is by no means confined to the upper rocks, but the purple sheets stretch down over the ridges of the rocks to below mid-tide level, even extending to the exposed Himanthalia zone. In the lower reaches a gradual succession from the linearis to the typical vulgaris state is noted, the latter being fully attained about April, when var. laciniata is also found growing on these rocks in small quantities. Both varieties, however, disappear rapidly towards the end of May and the beginning of June, and by the end of June there is hardly a frond to be found. The time at which this disappearance takes place seems to be determined by the weather, for from all accounts Porphyra appears to be unable to withstand the heat of the south coast, and in districts where it does exist all the year round, i. e. Clare Island (3) and the Faroes (2), its survival is probably due to the cooler climate and the spray with which it is saturated even at low water.

\section{Material AND Methods.}

The long thin fronds of Porphyra hanging down the sides of the rocks are only attached by minute adhesive discs, and these were detached by scraping the rocks with a knife. The fronds and discs were fixed on the spot in weak Flemming's solution in sea-water, allowing the fixative to act for thirty minutes only. In the laboratory the discs were examined and some were embedded in paraffin in the usual way; microtome sections from $3 \mu$ to $5 \mu$ in thickness were cut in a longitudinal direction, and were stained in Heidenhain's iron-alum-haematoxylin (twenty-four hours), counterstaining in safranin in 70 per cent. alcohol (thirty minutes). Hand sections were also examined and preparations made from discs, which in some cases were boiled in caustic potash to separate the tissues. This, however, was not found to be a satisfactory method, as although it fulfilled its object in removing the gelatinous 'cuticle' (1, p. 5) which surrounds the tissues, yet at the same time it causes the hypha-like filament composing the disc to swell up and assume new forms, so that it was impossible to tell whether one were examining an artificial or the natural state of these threads. Instead preparations were made by teasing and pressing the disc structures until the tissues had become separated one from another and then staining in aqueous safranin. 
Porphyra is very rarely found epiphytic, but two specimens of $P$. var. laciniata growing on Fucus serratus were obtained from Shanklin, and these were fixed, embedded, and stained as above. Also some embedded material of var. laciniata growing on a post of an old breakwater at Pegwell Bay, Kent, was kindly given me by Dr. Delf, to whom my most grateful thanks are due both for this and some slides which she had previously made from it, and also for her helpful criticism and suggestions throughout. Microtome sections of this material were stained in safranin (thirty minutes) and very dilute methylene blue (three minutes), and it was found that this double stain differentiated clearly the woody tissue and the hypha-like threads of the attaching disc.

\section{Description of the Disc.}

The attaching organs of the British species of Porphyra have not previously been described in detail, though they are mentioned by several writers on the Bangiales. Harvey (6) states that the minute disc is always present, and in the species with an upright thallus is accompanied by a short linear stipe which is absent in the horizontal thallus of $P$. laciniata, Ag. The internal structure of this disc has been examined by Thuret (9, p. 59), who notes that in var. vulgaris the discs are formed by 'des prolongements radiculaires' of the lower cells of the thallus, and this is corroborated by Berthold (1, p. 3), and Hus (7), who adds that these threadlike projections may swell up in contact with the substratum. The only other fact recorded in regard to these attachments is that Thuret (9) believes that the reproductive cells may be formed from the actual cells taking part in disc formation, but this is denied by later writers.

On examination these minute attaching organs were found to consist typically of discs, circular in outline and from 0.5 to several $\mathrm{mm}$. in diameter, which adhere firmly to the substratum of wood or stone. In longitudinal section it is seen that this tenacious structure is made up of interwoven filaments formed as outgrowths from either surface of the thallus cells. The vegetative thallus is originally one cell thick, and in the upper part of the disc the single layer of cells is continued down the centre of the structure. (Cf. Text-fig. I, C.)

The thallus cells are typically brick-shaped and possess a stellate chromatophore with radiating arms, the ends of which are flattened against the cell-wall, a central pyrenoid and a lateral nucleus lying between the two arms of the chromatophore. On dissection the young filament is seen to arise as a short blunt protuberance (Text-fig. 2, A); when this is about equal in length to the cell itself, a portion of the arm of the chromatophore nearest to the growing tube breaks off and passes down to the tip of the young filament; at the same time the nucleus divides and the daughter nucleus passes into the filament (Text-fig. 2, A); as the latter elongates, 
a further portion of the chromatophore passes down, and this is seen causing a bulge in the wall in its journey towards the tip (Text-fig. 2, B).

The full-grown filament, before modifications have taken place, consists of a very long, exceedingly narrow refractive tube, with thick gelatinous walls and no cross-walls. A typical filament with its disc cell attached, which was separated out and measured, was found to be over II $\mathrm{mm}$. in length; in discs of Ulva with a similar structure Thuret (9) states that the filaments may reach to $\mathrm{mm}$. (cp. 4). The staining contents consist, of numerous fragments of chromatophore and many highly refractive minute

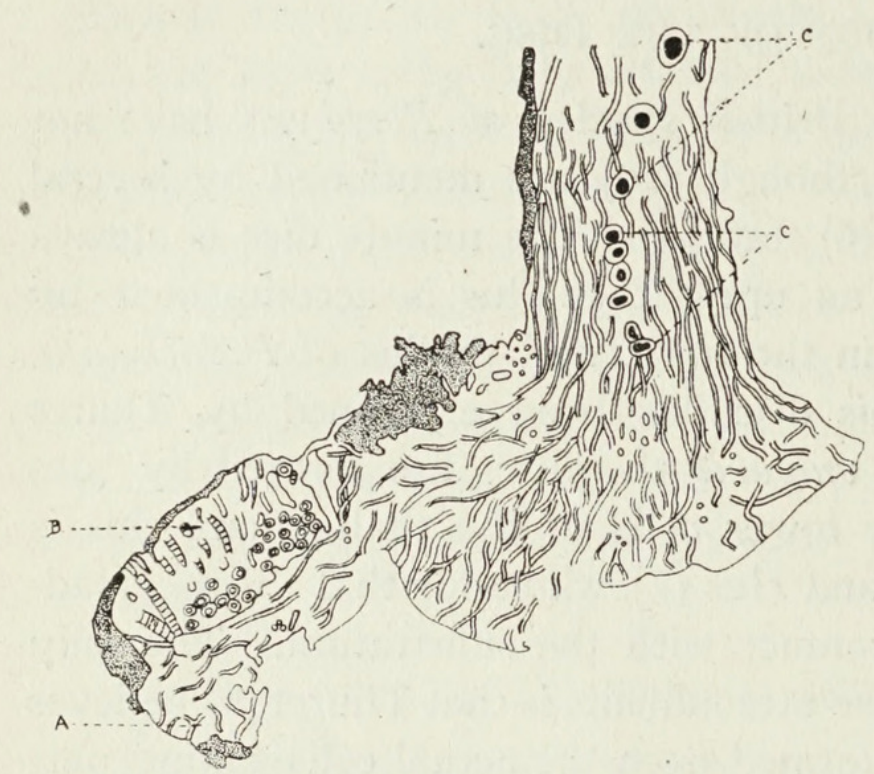

TEXT-FIG. I. Longitudinal section through the attaching base of Porphyra umbilicalis, showing the central rows of cells (C) and the interwoven branching filaments. At A the proliferating portion is seen, and at $\mathrm{B}$ this portion is occupied by a colony of bluegreen algae. Drawn with camera lucida. $\times \mathbf{I} 50$.
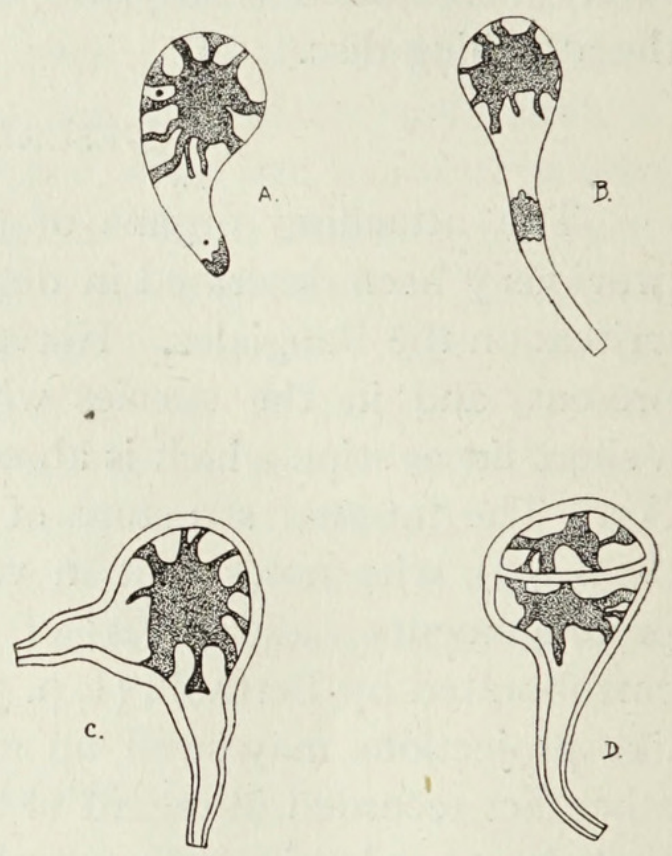

TEXT-FIG. 2. Outline drawings of the cells and filaments composing the disc of Porphyra. At A the first stage in the formation of the young filament is seen, showing the chromatophore and nucleus in the tip. B shows a second portion of chromatophore passing down. C, a disc cell producing two filaments. D, a disc cell with a cross-wall. Camera lucida drawings. $\times 75^{\circ}$.

nuclei which are scattered along the length of the tube (Pl. I, Fig. I). As a rule only one filament is formed from a single cell, though occasionally two may be produced (Text-fig. 2, C) ; spores, on the other hand, have never been seen forming from a disc cell, and only in one case has the latter been seen with a cross-wall (Text-fig. 2, D).

The disc filaments pursue a winding course towards the base of the attachment, becoming interwoven with one another and forming a resistant tissue several layers in thickness. As they approach the substratum alterations take place in their structure, and the shorter threads, which are formed from cells with thick gelatinous walls in the centre of the tissue, appear to be twice the diameter of the normal filament. The tips of the majority of 
the threads now become awl-shaped with the nuclei aggregated at the apex, which is protected by a swollen wall, suggesting that a boring action is necessary if the dense tissue of the disc is to be penetrated.

The disc filaments may be simple or branched, branching as a rule taking place at a swelling and characteristically forming distinct two-armed structures with barbed inner edges having the appearance of clasping organs (Text-fig. 3, D). More rarely a new structure in the shape of a miniature hapteron has been dissected out, and in two cases this consisted of five long arms terminating a filament and themselves branching again at the tips
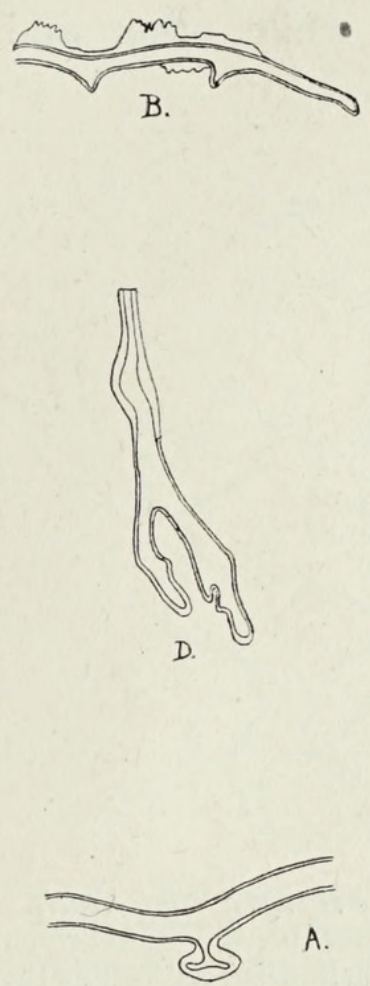
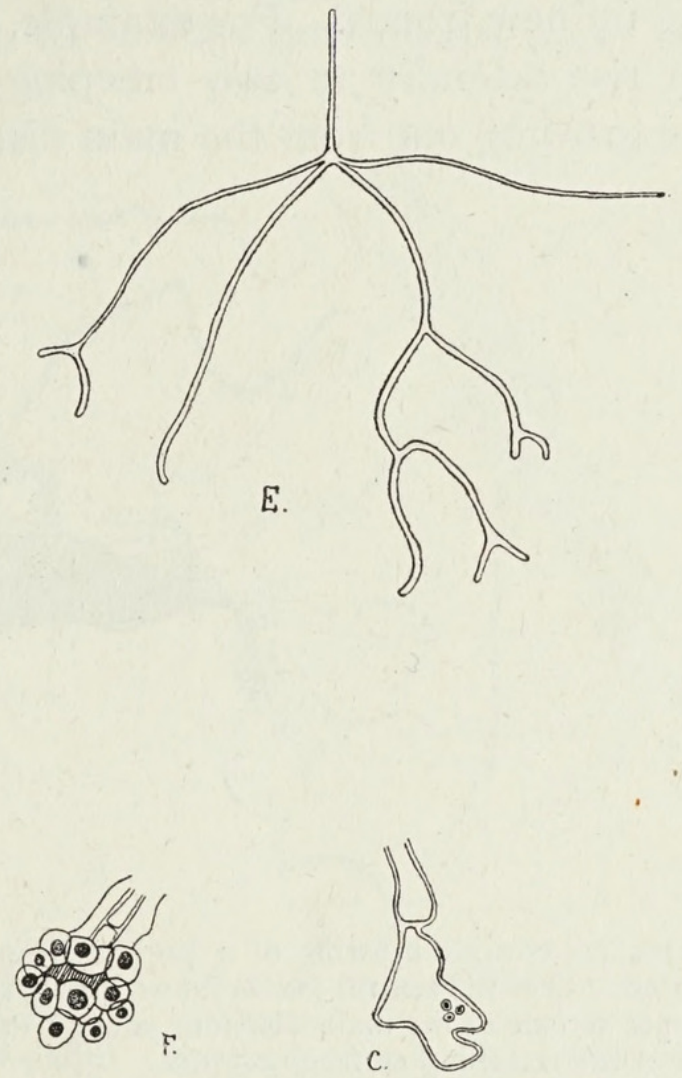

Text-FIG. 3. Outline drawings showing the modifications undergone by the filaments of the disc. A and B. Sucker and runner formed as attachment to the rock. C. A swollen multinucleate tip. D. A branching tip. E. Hapteron structure with five long arms. F. A group of cells cut off at the tip of a filament. Camera lucida drawings. $\times 75^{\circ}$.

(Text-fig. 3, E). In other cases the hapteron was in a rudimentary state, a filament ending in short blunt arms which were arranged in more than one plane with regard to the substratum. On finally reaching the substratum other modifications may take place; the filament may creep along at right angles to its former course, here and there putting out suckers which establish a connexion with the rock (Text-fig. 3, A and B). More often the tip or some other portion swells up to give a multinucleate organ (Text-fig. $3, \mathrm{C}$ ), which often attains a great size, and may divide up to give cells which are clamped to the ground by their gelatinous walls (Text-fig $3, \mathrm{~F})$. The variety of forms assumed by these modified filaments is endless 
and to some extent explains the tenacious adherence to the rocks that is exhibited by the discs of Porphyra.

As the filaments forming the disc wind downwards towards the base, many of them turn outwards and form the outer tissue of the structure, the free tips being enclosed in thick gelatinous walls. In older discs cells are sometimes cut off in great numbers from these tips, each with a single nucleus; these cells may be aggregated together and form a compact parenchymatous layer on the outer surface (Text-fig. 7, B). The interest of this differentiation of tissue lies in the fact that this parenchymatous tissue, is capable, by cell division, of creeping along the surface of the ground and of putting up new fronds. For example, in Text-fig. 4 a large central disc has given rise laterally to two creeping discs, while other and younger fronds are growing out from the main disc.

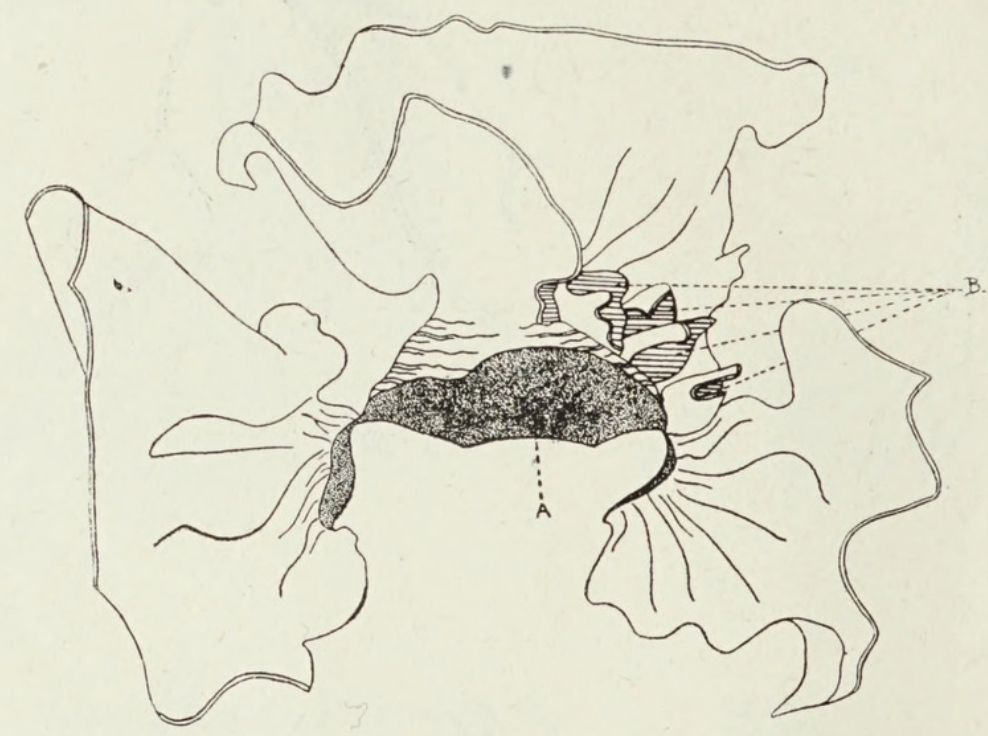

TeXT-FIG. 4. Outline drawing of a proliferating disc of Porphyra umbilicalis. The actual attaching surface (A) of the central disc is shown giving rise on either side to lateral attaching surfaces. From the upper surface of the main disc four young fronds have arisen (B) as well as the main frond. Total length of the attaching surface, $5.5 \mathrm{~mm}$.

That vegetative reproduction takes place in this way by a creeping and proliferating disc has been shown by Hus (7) for an epiphytic species of Porphyra-P. naidum, And.-from the Pacific coast of North America. This species has a parenchymatous or 'prothallial' base from which new fronds are developed; the base consists of small disc-shaped outgrowths which are one cell in thickness and gradually creep over the blades of Zostera; here and there the tissue becomes several layers thick, and from the external layer short blunt protuberances are put out which develop into fronds. I have also noted something similar in Enteromorpha compressa, for in a slide lent me by Dr. Delf two young narrow vertical fronds of Enteromorpha are clearly connected by a horizontal creeping parenchymatous base, one layer of cells in thickness (Text-fig. 5). This type of vegetative reproduction by a proliferating base seems to be present in 
the British species of Porphyra, but whether the discs perennate during the summer season when the fronds are absent, and put up new fronds in the autumn, has not yet been ascertained.

\section{SPORELings.}

It was noted at Swanage that the young fronds of Porphyra were usually found growing either in connexion with circular dark patches of the blue-green alga, Rivularia atra, or else among a layer of débris on the rocks, composed of mud and filaments of microscopic algae. This is probably not a case of symbiosis, as it does not always occur, but it is

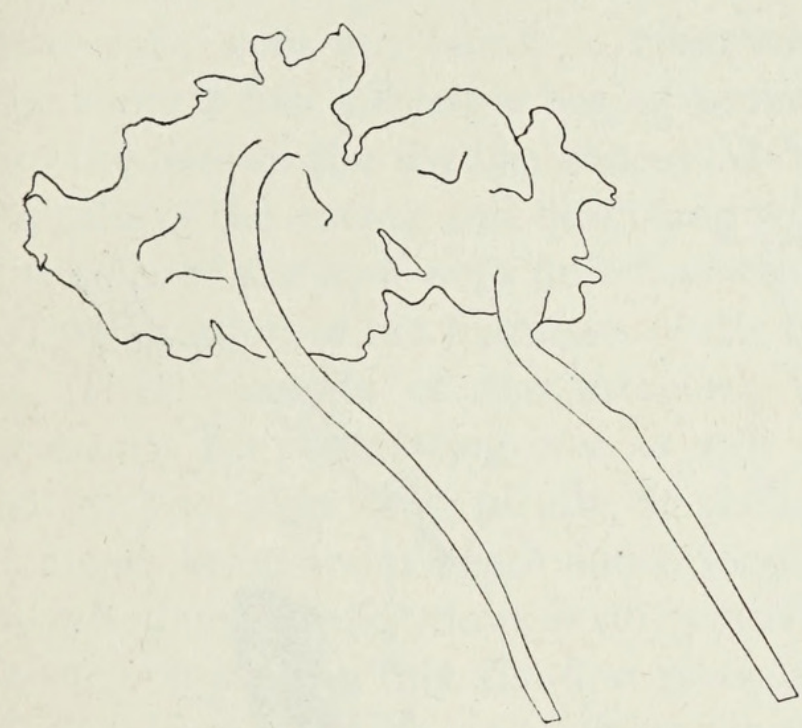

TeXT-FIG. 5. Outline drawing of a young sporeling of Enteromorpha compressa, showing the creeping prothallial base (one layer of cells thick) and two linear fronds arising from it. Drawn with camera lucida. $\times 60$.

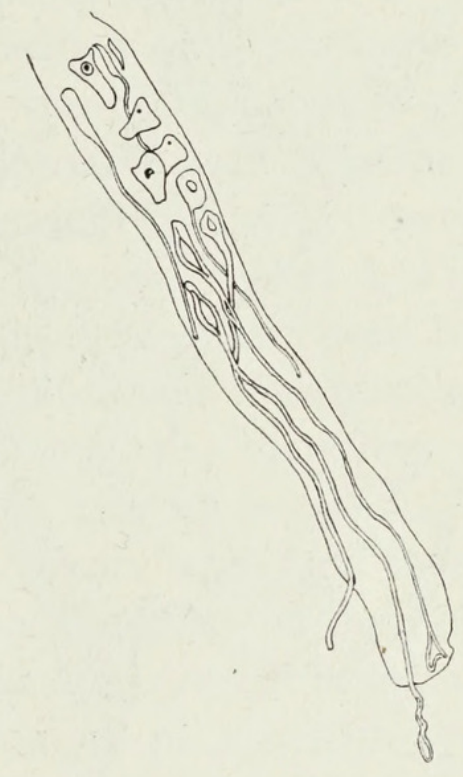

Text-Fig. 6. Outline drawing of the base of the sporeling seen in Plate I, Fig. 2, showing the first six rhizoids enclosed partially in a gelatinous sheath. Camera lucida drawing. $\times 65^{\circ}$.

likely that germination takes place more readily in this substratum as the débris serves to protect the sporlings in rough weather. Even when no fronds were visible to the naked eye, dissection and examination of the tangled material would occasionally reveal a sporeling. The youngest plant thus dissected out was only $0.34 \mathrm{~mm}$. in length and $0.03 \mathrm{~mm}$. at its widest point; it consisted of about seventy to eighty cells, a large proportion of which were modified to form rhizoids (Pl. I, Fig. 2). Four of these had elongated greatly, and of these one had a swollen tip and another was branched to form a clasping organ at the base (Text-fig. 6). The formation of filaments which will later combine to build up a disc takes place therefore at a very early stage. 


\section{Discussion of Cases of Epiphytism.}

Although Porphyra is typically a rock-dweller, yet many breakwaters stretching out to sea have their vertical sides clothed with the purple fronds. Material taken from such a source showed, in longitudinal sections through the attachment and substratum, the characteristic structure of a normal disc on the exterior of the wood (Text-fig. 7), several fronds with gelatinous walls arising from the upper part of the disc, while the external filaments of

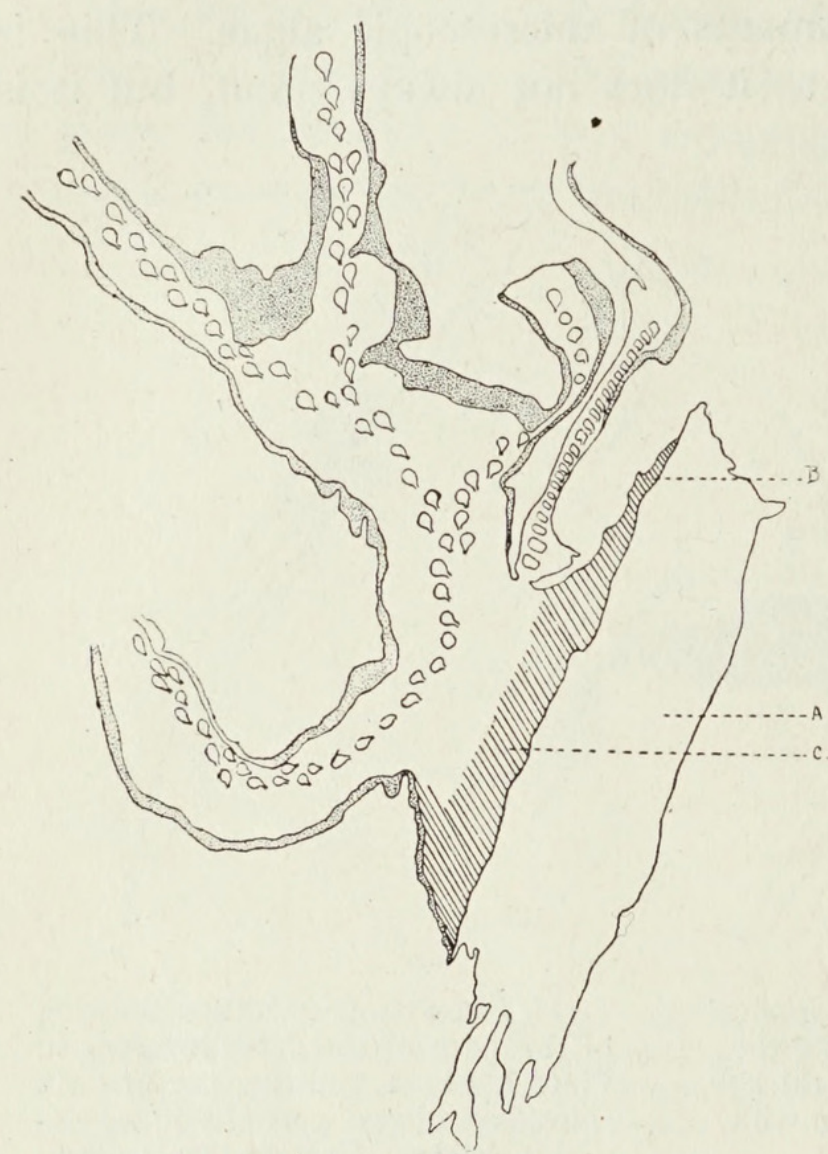

TEXT-FIG. 7. Outline drawing of a longitudinal section of Porphyra umbilicalis growing on wood (A), showing the disc attachment with creeping base (B) and thickened tissue formed by branching and division of the filaments (C). Five fronds with thick gelatinous walls (stippled) are being given off from the disc. Cells giving rise to the filaments somewhat diagrammatic. Camera lucida drawing. $\times 50$.

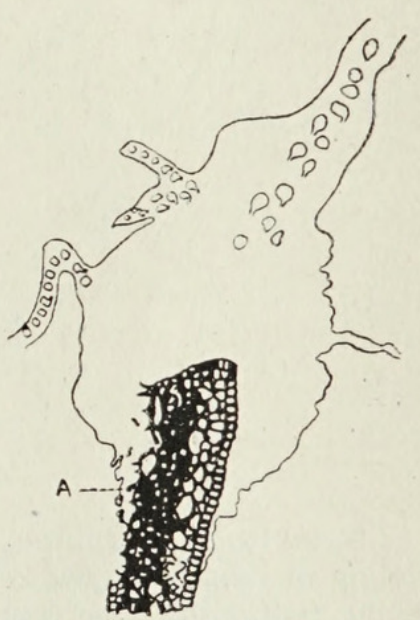

TExT-Fig. 8. Outline darawing of a longitudinal section of Porphyra umbilicalis, var. laciniata, on Fucus serratus, showing irregular attaching base of Porphyra creeping along the host. Fig. 5 of Plate I is taken from the region $\mathbf{A}$, where the cells of the host are disorganized. Cells of host and epiphyte somewhat diagrammatic. Camera lucida outline. $\times 50$.

the latter had undergone modification and were creeping along the surface of the post. The awl-shaped filaments in the interior of the disc had penetrated the xylem to a considerable distance, and the cells of the latter were very disorganized. Where the threads had met with any considerable resistance, they had swollen to an enormous size and formed large circular or irregular multinucleate parenchymatous swellings within the tissues of the xylem (Pl. I, Fig. 3). Where space permitted, the tips of the threads, instead of swelling, had cut off cells, each with a single nucleus and 
vacuolated protoplasm, and these cells are seen as circular patches with gelatinous walls within the woody tissues (Pl. I, Fig. 4). The penetration of the host appears to be very complete, for the wood of the post is disorganized and riddled with these parenchymatous masses and tissues of cells.

In the case of the material of Porphyra umbilicalis on Fucus serratus, the thallus of Fucus was attached when found near low-water mark, but the serrated lamina had completely disappeared and only the midrib of the frond was left; at the top of this a plant of $P$. laciniata was found growing.

Sections showed that it was attached, by a large spreading base formed in the usual way from interwoven filaments, and giving rise at the edges to new fronds (Text-fig. 8). As the winding filaments approached the host, they branched frequently and the ends became swollen and gelatinous, but cross-walls were not found so commonly as in the material on the post. The threads had a forcible boring action and penetrated both between and into the cells of the thallus, and could be seen to a great depth traversing the cells of the cortex and branching within the cell cavities (Pl. I, Fig. 5). The cells of the host were full of contents and appear to have been living, but penetration of the filaments of the disc rapidly induced disorganization.

The filaments of the attaching disc of Porphyra, therefore, show a capacity for penetrating into as well as between cells of a cellular host, though the alga is typically a rock-dweller. From the fact that the filaments bring about death and disorganization of the cells of the host, it must be inferred that there is no symbiotic relationship present in this case; on the contrary, in this, the first recorded examination of a British species of Porphyra growing on a living host, practically all conditions of true parasitism are fulfilled.

\section{Summary.}

I. The three varieties of Porphyra umbilicalis, var. linearis, var. vulgaris, and var. laciniata, grow commonly in exposed positions and are attached to the rocks, \&c., by minute adhesive discs.

2. Observations corroborate the view put forward by Harvey that the narrow form of frond known as var. linearis is only a growth-form of var. vulgaris.

3. The attaching discs of Porphyra are capable of lateral extension and may proliferate into new branches.

4. The disc is made up of numerous interwoven threads of two kinds which are formed as outgrowths from the thallus cells:

(1) long slender filaments; (2) short stout ones from the lowest cells.

5. Filaments near to, or in contact with, the substratum swell up and branch or produce suckers or hapterons. Filaments on the exterior of the disk may produce a parenchymatous tissue by branching or division. 
6. Modifications in the disc filaments are shown to take place very early in the life of the sporeling.

7. Porphyra grows usually on a substratum of rock, but in plants occurring on breakwaters the filaments are shown to have the power of penetrating the dead woody tissue. Porphyra has hitherto very rarely been found epiphytic, and never parasitic, but in two plants found on Fucus serratus the disc filaments had penetrated the living cells of the host. This seems to indicate the capacity for either epiphytism or parasitism if once secure contact is obtained.

\author{
Westfield College, \\ LONDON, \\ July, 1922.
}

\title{
REFERENCES.
}

1. Berthold, G.: Die Bangiaceen des Golfes von Neapel. Fauna u. Flora des Golfes von Neapel. Mon. vii, I882.

2. Börgesen, F. : Algal Vegetation of the Færöese Coasts, I905, p. 830 .

3. Cotton, A. D.: Clare Island Survey. Part XV: Marine Algae. Proc. Roy. Irish Academy, vol. xxxi, p. 30.

4. Delf, E. M. : Attaching Discs of the Ulvaceae. Ann. Bot., xxvi, No. 102, I9I 2, p. 403.

5. Derick, C. M. : Notes on the Development of the Holdfasts in certain Florideae. Bot. Gaz., Oct. 1899, p. 264 .

6. Harvey: Phycologia Britannica. Vol. iii, Rhodophyceae, i.

7. Hus, H. T. A. : Account of the Species of Porphyra found on the Pacific Coast of N. America. Proc. Californian Acad. Sc., 3rd ser., vol. ii, 6, I902, p. I73.

8. Tobler-Wolff, G.: Zur Biologie von Polysiphonia fastigiata. Beihefte z. Bot. Centralbl., Bd. xxiv, 2. Abt., 1909, p. II3.

9. Thuret et Bornet: Études Phycologiques, i 878 .

\section{EXPLANATION OF PLATE I.}

Illustrating Miss Grubb's paper on the Attachments of the British Species of Porphyra.

All figures drawn with a No. 3 eyepiece (Swift) and D.D. objective (Zeiss), except Fig. 2, which was drawn with a No. 3 eyepiece and A.A. objective (Zeiss), and Fig. I, which was drawn with a No. 4 compens, ocular (Zeiss) and a $\frac{1}{12}$ apochromatic objective (Swift).

Fig. I. Apex of a typical disc filament with nuclei ( $\frac{1}{12}$ apochromatic).

Fig. 2. Young sporeling. $\times 25^{\circ}$.

Fig. 3. Transverse section of swollen tips of disk filaments (stippled) in tissues of the wood. $\times 75^{\circ}$.

Fig. 4. Transverse section of a group of cells formed from the apex of a disc filament in the wood of the post. $\times 750$.

Fig. 5. Filaments from the base of the disc of Porphyra boring into the tissues of Fucus serratus. $\times 75^{\circ}$. 
Figures.

PAGE

each leaf. 43-9. Transverse sections through a petiole in which a slightly more complex type of fusion of the adaxial bundles with the abaxial constituents occur. 44-9 are from the petiole which is fellow to that shown in 43 , the adaxial bundle on the right behaving similarly, while that on the left shows a still further complexity (HOLDEN and BEXON). . . . . . . . . .

50-5. Transverse sections of a petiole in the upper part of which three feebly developed medullary bundles occurred locally, but died out at a lower level without fusion. The one persisting longest $\left(5_{1} a\right)$ was represented by phloem only for the greater part of its course. 54 and 55 show the bundle fusions near the base of the petiole (HOLDEN and BEXON)

56-60. 56-9. Transverse sections of a petiole, showing a single symmetrically situated medullary bundle $\left(5^{6}\right)$ which at a lower level unites with half the adaxial bar $(57)$. $5^{8}$ and $\mathbf{5 9}$ show differing methods of bundle fusion on opposite sides of the same petiole. 6o. Diagrammatic representation of the vascular system of the young seedling shown as if cut through in the intercotyledonary plane and spread out flat (HoLden and BEXON).

6I-7. Series of semi-diagrammatic outlines, showing the transition features of seedling $J$. The small crosses in $6_{3}$ and 64 mark the positions of the single protoxylem-like elements which appear sporadically in the hypocotyl ; the arrow in 64 marks the position which would be occupied by $C p x_{0}$ if it had persisted (HOLDEN and BEXON)

68-74. 68-72. Diagrams illustrating the three types of transition from the cotyledons to the hypocotyl described in the text. 72-4. Comparative diagrams illustrating the transition features in Acer, Abronia, and Calycanthus (Holden and BExon) .

I. Typical broad bean seedlings after five days' growth in a nutrient solution with or without boric acid (WARINGTON)

2. Broad beans grown in water-culture solution containing different quantities of boric acid (WARINGTON).

3. Total dry weight of broad beans (average of five plants). A. Grown without boric acid for different periods; $I: 50,000$ then added. B. Grown with boric acid for different periods; I : 50,000 then removed (WARINGTON) . . . .

4. Barley grown in water-culture solution containing different quantities of boric acid (average of five plants) (WARINGTON)

5. Broad beans grown in pot culture with various quantities of boric acid mixed throughout the soil (average of five pots) (WARINGTON) . . . . .

6. Barley grown in pot culture with varions quantities of boric acid mixed throughout

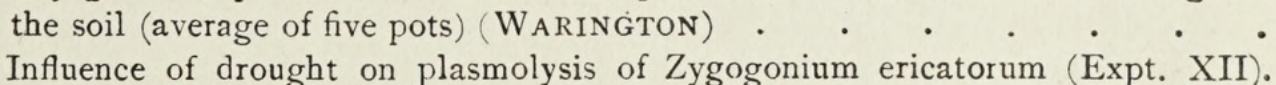

I 2. I. Influence of drought on plasmolysis of Zygogonium ericatorum (Expt. XII).
2. Effect of drought on Zygogonium (Expt. XVI) (FRITSCH and HAINES)

3, 4. 3. Effect of drought on Hormidium flaccidum (Expt. XXVI). 4. Ditto on Hormidium-stage of Prasiola (Expt. XXVII) (FRITSCH and HaINES) . . .

5. Influence of drought on plasmolysis of moss protonema (Expt. XV) (FRITSCH and HaINES).

6. Effect of drought on Pleurococcus Naegelii (Expt. XXX). Material soaked with water after nearly four weeks (FRITSCH and HAINES) . . . .

7. Recovery from plasmolysis in a sealed slide. The heavy lines show the results for Zygogonium (Expt. XVI), the thin lines those for moss protonema (Expt. XV)

8. Recovery from drought in the case of Zygogonium (Expt. XVI) (FritsCH and HAINES).

\section{ERRATA}

Page 400, Fig. 9, for Condiophores read Conidiophores.

" 423 , Fig. 23 , for solution read solutions.

$" 45$ i, 1.8 , for sixty reaa' sixty-two. 


\section{$2 \mathrm{BHL}$ Biodiversity Heritage Library}

Grubb, Violet M. 1923. "The attachments of Porphyra umbilicalis, (L.) J. Ag." Annals of botany 37, 131-140.

https://doi.org/10.1093/oxfordjournals.aob.a089829.

View This Item Online: https://www.biodiversitylibrary.org/item/270686

DOI: https://doi.org/10.1093/oxfordjournals.aob.a089829

Permalink: https://www.biodiversitylibrary.org/partpdf/319072

\section{Holding Institution}

New York Botanical Garden, LuEsther T. Mertz Library

\section{Sponsored by}

BHL-SIL-FEDLINK

\section{Copyright \& Reuse}

Copyright Status: Public domain. The BHL considers that this work is no longer under copyright protection.

This document was created from content at the Biodiversity Heritage Library, the world's largest open access digital library for biodiversity literature and archives. Visit BHL at https://www.biodiversitylibrary.org. 